\title{
DETERMINATION OF SOIL VOLUME BY PLANIALTIMETRIC SURVEY METHODS
}

\author{
Luiz S. Vanzela ${ }^{1 *}$, Osvaldo Araujo Junior ${ }^{2}$, Ronaldo C. Lima ${ }^{3}$ \\ ${ }^{1 *}$ Corresponding author. Universidade Brasil/ Fernandópolis - SP, Brasil. \\ E-mail: luiz.vanzela@universidadebrasil.edu.br | ORCID ID: https://orcid.org/0000-0002-2192-9252
}

\section{KEYWORDS}

GNSS, geometric leveling, trigonometric leveling, geomatics.

\begin{abstract}
Considering the importance of topographic surveys to determine soil volumes and study efficient and accessible alternatives for this operation, this study aimed to analyze methods and respective equipment for planialtimetric surveys to determine soil volume. An experimental grid was installed in an area locate in Fernandópolis, SP, Brazil, in which quotas were measured by geometric leveling (standard method), trigonometric leveling, leveling with receivers of the Global Navigation Satellite System (GNSS) by relative (frequencies L1/L2) and absolute positioning (code C/A) and extraction of altitudes in digital terrain model from SRTM and ASTER images. In comparison to geometric leveling, trigonometric leveling was the most accurate in determining soil volume $(0.6 \%$ error), followed by GNSS leveling by relative positioning ( $23.7 \%$ error), and extraction of altitudes by SRTM (32.0\% error) and ASTER images (38.3\% error). GNSS leveling by absolute positioning presented the highest error in determining soil volume $(287.4 \%)$ compared to the other methods.
\end{abstract}

\section{INTRODUCTION}

The last decades have been marked by a rapid evolution of topography, from the execution of the field survey to the preparation of the product. A large part of this advance has occurred with the use of the digital medium, with sophisticated electronic equipment, which automates with efficiency and speeds the various stages related to the topographic survey. The topography is necessary at the beginning of any project, as it is from the measurement and detailing of the area to be built that its delimitation, dimensions, and conditions are obtained for the construction of houses, roads, among others (Pittella \& Salbego, 2014). Testoni et al. (2009) highlighted the importance of operations necessary to achieve the objectives of topography, such as measuring angles and distances, carrying out calculations and drawings to represent in the plan, in addition to elements measured on the terrain. The topographic survey consists of the accuracy of the graphical representation, in letter or plan, of all important information existing in a terrain of a certain area, containing in scale all the details that were surveyed (Coelho Junior et al., 2014).

According to the Brazilian National Standards Organization (ABNT, 1994), the complete process of obtaining measurements of the terrain is called planialtimetric survey, as it allows the representation of planimetric (angles and distances) and altimetric information (quotas and altitudes), providing the largest possible number of terrain surface information.

Among the precision planialtimetric survey works, soil volume calculation for the execution of terrain leveling works by cuttings and embankments stands out (Camargo, 2017), as this operation is fundamental for the execution of buildings, roads, among others. Several equipment and methods are available for this type of survey, ranging from the most traditional such as levels, theodolites, and total station, to the most modern ones, such as remote sensing and Global Navigation Satellite System (GNSS), distinguishing themselves in the costbenefit ratio, precision, and accuracy (Rossi et al., 2015).

The most modern methods that use satellite signals in topographic surveys, such as remote sensing and global positioning systems (Doma \& Sedeek, 2019), have the advantage of the speed and ease of obtaining field data, as well as calculations and data processing to determine soil volume. On the other hand, more in-depth studies on the precision and reliability of these methods are still needed in order to replace the traditional methods of planialtimetric surveys with the use of theodolites and optical levels.

\footnotetext{
${ }^{2}$ UNESP/ FCA Faculdade de Ciência Agronômicas-Campus de Botucatu/ Botucatu - SP, Brasil.

${ }^{3}$ UNESP/ FCAT Faculdade de Ciência Agrárias e Tecnológicas/ Dracena - SP, Brasil.
}

Area Editor: Teresa Cristina Tarlé Pissarra

Received in: 7-20-2017

Accepted in: 12-9-2019 
Depending on the application, the requirements have a topographical rigor that makes its use unfeasible, as is the case with geometric levels, whose required precision may vary, according to NBR 13133 (ABNT, 1994), from low (standard deviation higher than $\pm 10 \mathrm{~mm} \mathrm{~km}^{-1}$ ) to very high (standard deviation lower than $\pm 1 \mathrm{~mm} \mathrm{~km}^{-1}$ ).

Considering the importance of the topographic process to determine soil volumes and study faster and accessible alternatives for this operation, this study aimed to analyze methods and the respective equipment for planialtimetric surveys to determine soil volume.

\section{MATERIAL AND METHODS}

\section{Location}

This study was conducted in an experimental area located on the Teaching and Research Farm of Universidade Brasil, in the city of Fernandópolis, SP, northwestern São Paulo State. The location of the experimental area is between the geographic coordinates $20^{\circ} 17^{\prime} 52.36^{\prime \prime}$ and $20^{\circ} 17^{\prime} 56.31^{\prime \prime} \mathrm{S}$ and $50^{\circ} 16^{\prime} 48.78^{\prime \prime}$ and $50^{\circ} 16^{\prime} 53.15^{\prime \prime} \mathrm{W}$ (Figure 1).

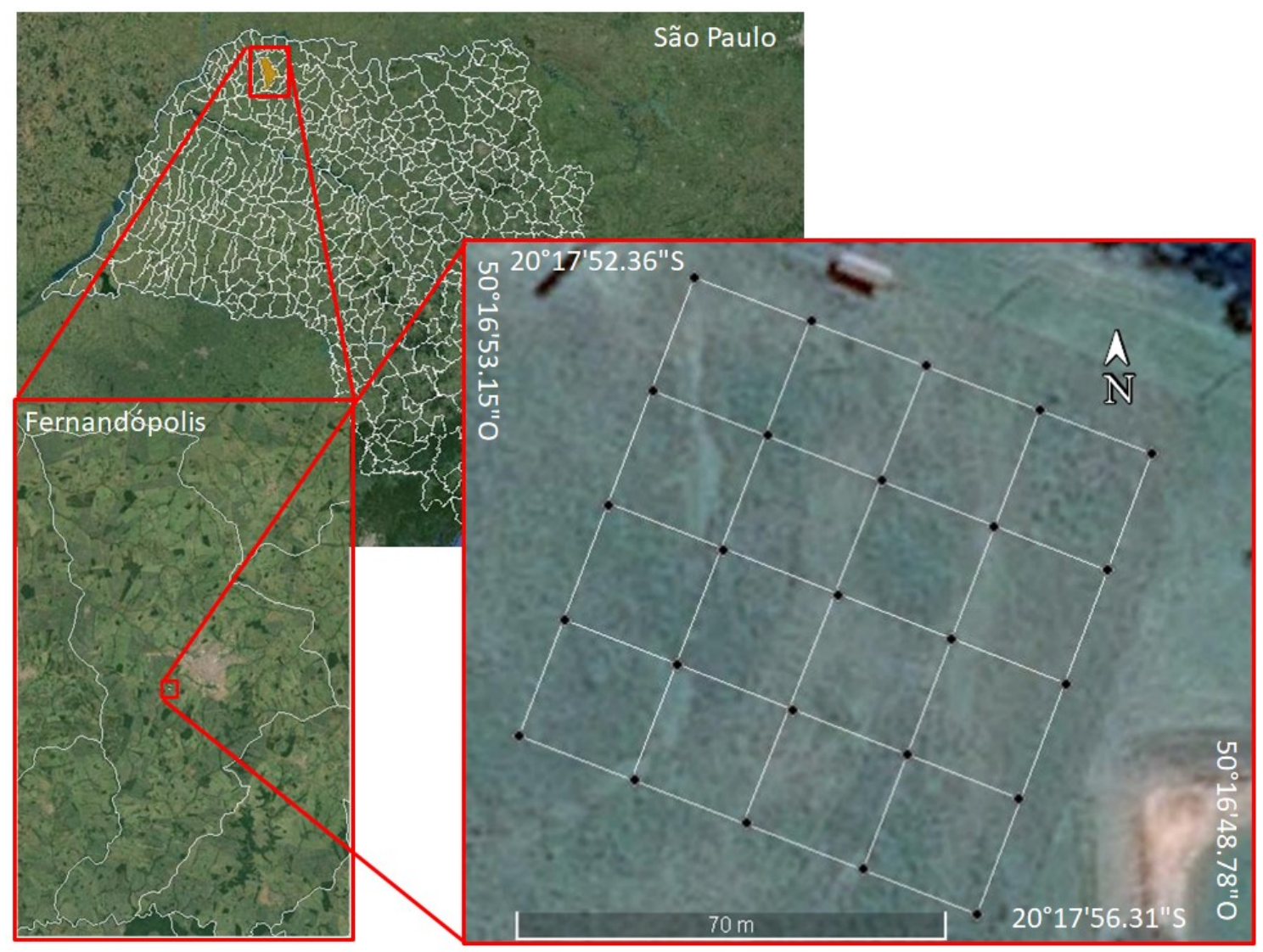

FIGURE 1. Location of the experimental area.

\section{Experimental area}

The experiment was installed on August 30, 2013, in an $80 \times 80 \mathrm{~m}$ experimental grid with points spaced at 20 $\times 20 \mathrm{~m}$, totaling 25 points, registered in the field using a total station from local topographic coordinates previously defined in linear measurements from a starting point. The project was outlined in the computer-aided design AutoCAD. The vegetation cover of the experimental area was a pasture of the genus Brachiaria, being one of the pastures belonging to University Veterinary Hospital, with classes of predominant slope between $0-2$ and 2-4\%, with a mean value of $2.89 \%$ (Figure 2 ). 


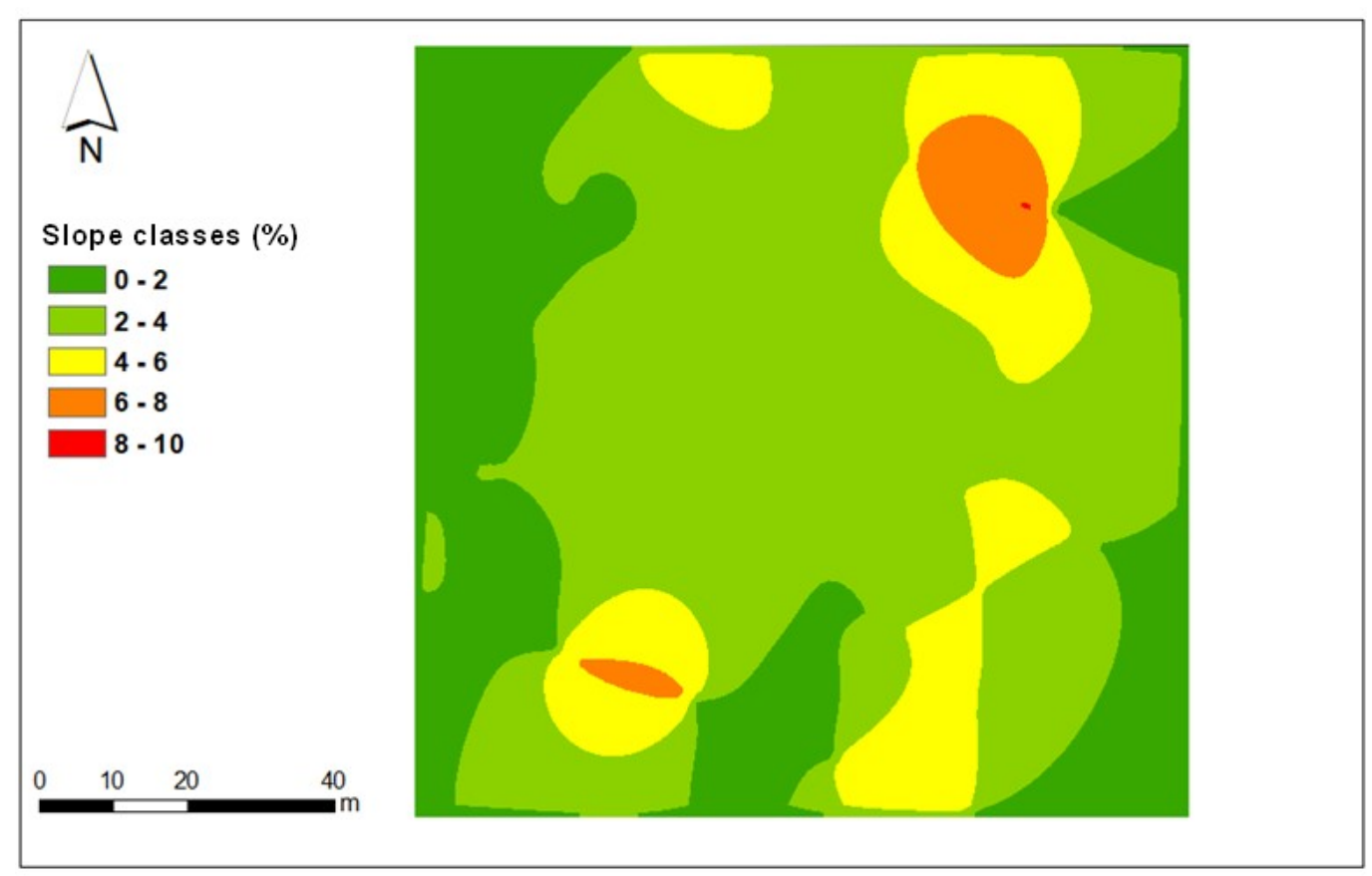

FIGURE 2. Slope map of the experimental area determined by geometric leveling.

Points located in the experimental area (grid) were represented by stakes. Georeferencing was carried out in one of the stakes as the base support (point 1 of the grid). A Magellan ProMark 500 GNSS receiver with double frequency (L1/L2) was used for this determination. The base support point was geo-referenced by static relative positioning, with an occupation time of 81 minutes and a recording rate of 1 second. The adjustment was carried out with reference bases of the Brazilian Network for Continuous Monitoring (RBMC) of Araçatuba (SPAR) and São José do Rio Preto (SJRP) (Table 1).

TABLE 1. RBMC bases used to adjust the coordinates of the base point in the experimental design.

\begin{tabular}{ccc}
\hline Name & Coordinates (m) \\
\hline SJRP & East (E) & 670708.25 \\
& North (N) & 7700722.08 \\
& Ellipsoidal height (h) & 535.91 \\
\hline SPAR & East (E) & 558150.93 \\
& North (N) & 7657311.90 \\
& Ellipsoidal height (h) & 410.35 \\
\hline Adjusted BASE* & East (E) & 575150.096 \\
& North (N) & 7755359.804 \\
& Ellipsoidal height (h) & 511.756
\end{tabular}

*Standard deviations $(\sigma)$ of the coordinates adjusted from the base support point: $\sigma \mathrm{E}=0.003 \mathrm{~m}, \sigma \mathrm{N}=0.003 \mathrm{~m}$, and $\sigma \mathrm{h}=0.016 \mathrm{~m}$.

The survey of the other points of the grid of the experimental area was carried out at the same time as the survey of the base point using the static relative survey using a PROMARK 3 receiver of a single frequency (L1), with a mean occupation time of 70 seconds and a recording rate of 1 second. The coordinates were adjusted and corrected with the base support point in the postprocessing of data (Figure 3). 
$\mathrm{B}$

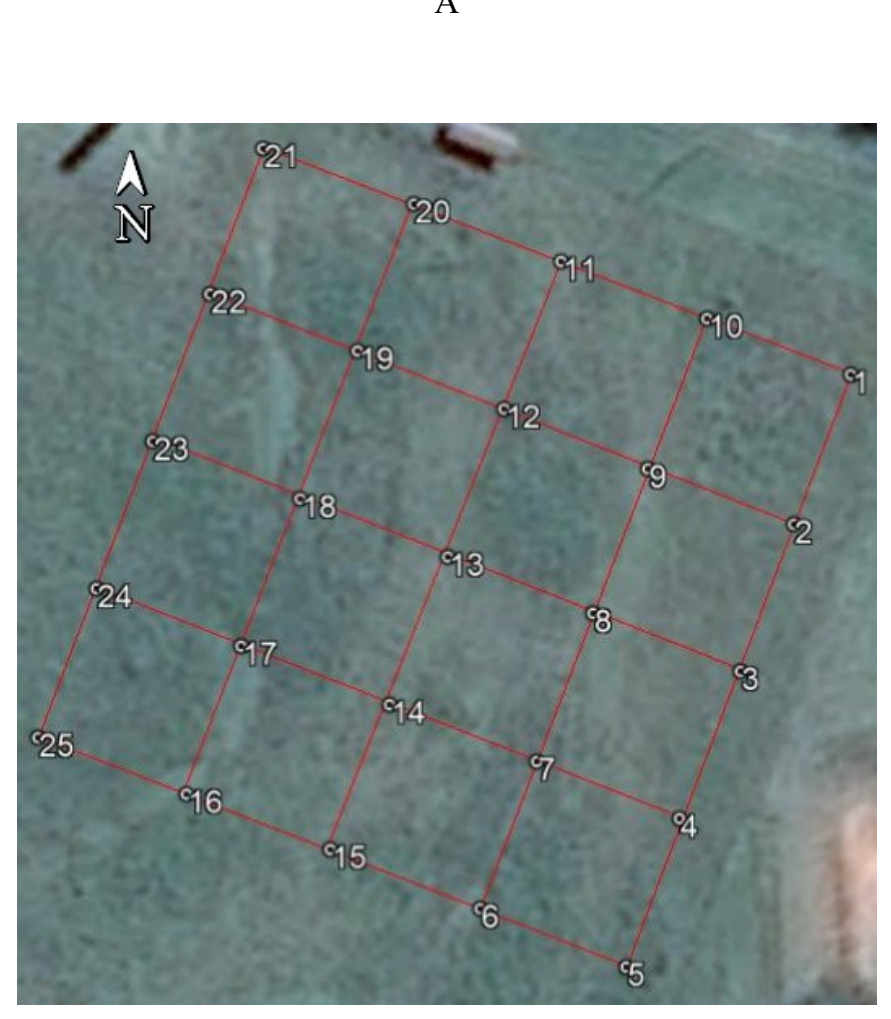

\begin{tabular}{|c|c|c|}
\hline \\
\hline Point & $\mathrm{E}(\mathrm{m})$ & $\mathrm{N}(\mathrm{m})$ \\
\hline 1 & 575140.26 & 7755352.99 \\
\hline 2 & 575132.95 & 7755334.14 \\
\hline 3 & 575126.10 & 7755315.59 \\
\hline 4 & 575118.28 & 7755297.02 \\
\hline 5 & 575111.43 & 7755278.31 \\
\hline 6 & 575092.91 & 7755285.75 \\
\hline 7 & 575100.17 & 7755304.30 \\
\hline 8 & 575107.41 & 7755322.99 \\
\hline 9 & 575114.44 & 775534 \\
\hline 10 & 575122.04 & 7755360.14 \\
\hline 11 & 575103.54 & 7755367.43 \\
\hline 12 & 575096.23 & 7755348.85 \\
\hline 13 & 575088.99 & 7755330.20 \\
\hline 14 & 575081.52 & 7755311.56 \\
\hline 15 & 575073.91 & 7755293.31 \\
\hline 16 & 575055.69 & 7755300.38 \\
\hline 17 & 575062.71 & 7755319.04 \\
\hline 18 & 575070.30 & 7755337.61 \\
\hline 19 & 575077.66 & 7755356.25 \\
\hline 20 & 575084.88 & 7755374.77 \\
\hline 21 & 575065.77 & 7755381.86 \\
\hline 22 & 575058.96 & 7755363.51 \\
\hline 23 & 575051.60 & 7755344.96 \\
\hline 24 & 575044.38 & 7755326.39 \\
\hline 25 & 575036.86 & 7755307.59 \\
\hline
\end{tabular}

FIGURE 3. Identification of grid points (A) and their respective corrected coordinates UTM Zone 22K, Datum WGS84 (B).

\section{Altimetric survey methods}

Level differences (LD) between grid points were initially determined for comparison between leveling methods considering the target sight point at ground level in front of the stake as the reference level. The surveys by all evaluated methods were carried out on August 30, 2013 (Table 2).

TABLE 2. Methods used for leveling in the experimental grid.

\begin{tabular}{ccc}
\hline Method & Equipment & Model/manufacturer \\
\hline Geometric leveling (standard method) & Automatic (optical) level of 0.2" stabilization accuracy & ZEISS \\
\hline Trigonometric leveling & Total station of 2" angular precision & $\begin{array}{c}\text { Standard } \\
\text { GEOMAX }\end{array}$ \\
\hline $\begin{array}{c}\text { GNSS leveling by the relative } \\
\text { positioning }\end{array}$ & Pair of GNSS receivers (L1/L2 frequencies) & $\begin{array}{c}\text { ProMark500 and 3 } \\
\text { MAGELLAN }\end{array}$ \\
\hline $\begin{array}{c}\text { GNSS/GPS leveling by absolute } \\
\text { positioning }\end{array}$ & GPS receiver (Code C/A) & $\begin{array}{c}\text { Etrex 10 } \\
\text { GARMIN }\end{array}$ \\
\hline $\begin{array}{c}\text { Extraction of altitudes in the digital } \\
\text { terrain model (DTM) }\end{array}$ & $\begin{array}{c}\text { ASTER (Advanced Spaceborne Thermal Emission and Reflection } \\
\text { Radiometer), with a geometric resolution of 30 } \mathrm{m}^{*} \text { of 11/30/2013 }\end{array}$ & NASA \\
\hline $\begin{array}{c}\text { Extraction of altitudes in the digital } \\
\text { terrain model (DTM) }\end{array}$ & $\begin{array}{c}\text { SRTM (Shuttle Radar Topography Mission), with a geometric } \\
\text { resolution of } 90 \mathrm{~m} \text { *f of } 09 / 23 / 2014\end{array}$ & NASA \\
\hline
\end{tabular}

*Original geometric resolutions of the images.

The first method used to determine level differences (LDs) between points materialized in the experimental grid was the geometric leveling (standard method). For this, the quota of point 1 of the grid was considered to be $100 \mathrm{~m}$ (basic support point), with quotas of the other points being obtained by leveling and counterleveling, with a total closing error (E) of $2 \mathrm{~mm}$, remaining below $8 \mathrm{~mm}$, which is the error tolerance of Class I Leveling (NBR-13133) for the distance surveyed in the grid.

The determination of LDs in the trigonometric leveling was carried out by irradiation, with the total station placed at the basic support point (point 1) and with the reverse aligned at point 2 . Then, the station coordinates were configured as adjusted for point 1 and assigning the quota $100 \mathrm{~m}$. Angles and distances were measured from the same point from a known reference line for LD calculation.

The GNSS survey (relative positioning) allowed obtaining ellipsoidal altitudes of all points in the experimental grid and the respective LDs with the receiver (rover) used in the perimeter survey. The quota $100 \mathrm{~m}$ was assigned to point 1 of the experimental grid, from which the quotas of the other points were determined. 
The device for the GNSS/GPS survey (absolute positioning) was positioned close to the soil, in front of the stake, and only one coordinate was registered with the respective altitudes. Then, the LDs were calculated between grid points. The quota $100 \mathrm{~m}$ was assigned to point 1 , from which the quotas of the other points were determined.

In addition, coordinates in the GNSS and GNSS/GPS positioning methods were not converted into local topographic coordinates, nor orthometric altitudes were obtained, as the main objective of this study was to determine the precision of methods conducted more quickly and simplified, as it is usually performed in agricultural activities.

The calculation of LDs, based on ASTER and SRTM images, was carried out by extracting altitudes. For this, the georeferenced experimental grid and the respective ASTER and SRTM DTMs (digital terrain

A

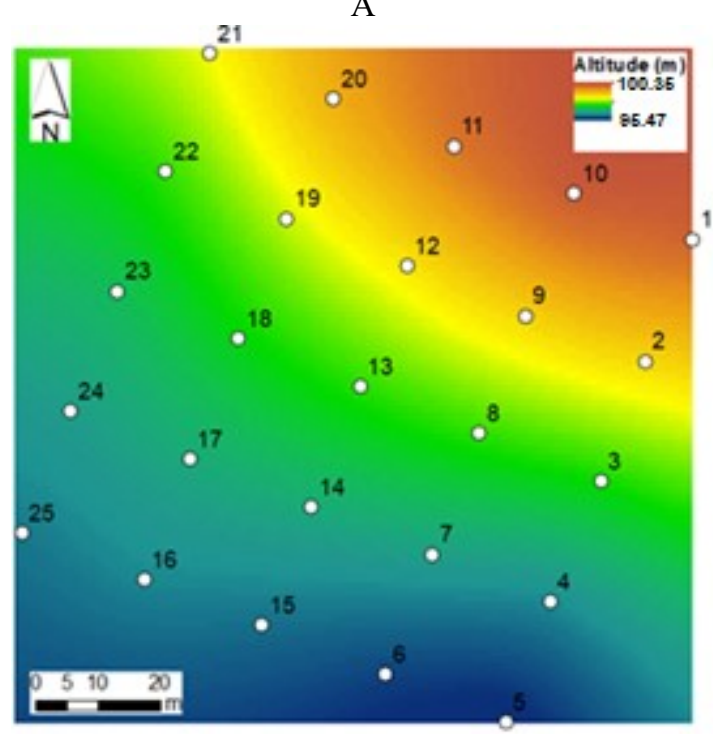

models) were imported into the software Global Mapper. Subsequently, the altitudes were extracted from DTMs at grid points (Figure 4), and LDs were determined by the difference in the altitude between these points. Thus, considering point 1 as a quota $100 \mathrm{~m}$ and having LDs between points, the local topographic quotas of the other grid points were determined.

After the quotas were standardized in all methods, always considering the point 1 in the grid as a quota $100 \mathrm{~m}$ (basic support point), the quoted grids were imported into the software DataGeosis Office version Educational, from which triangular grids (TIN) were generated and then DTMs. Then, soil cut volumes were determined using the Cutting/Embankment tool of the software DataGeosis Office version Educational, considering as the lower altimetric reference plane the quota $100 \mathrm{~m}$ and planimetric limits delimited by points $1,5,21$, and 25 .

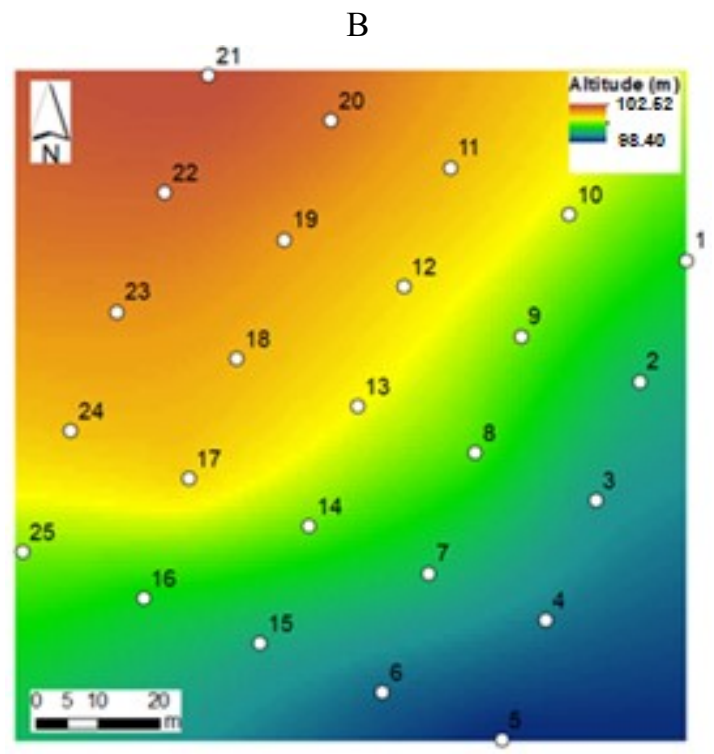

FIGURE 4. SRTM (A) and ASTER (B) images overlay on the experimental grid for altitude extraction.

The geometric leveling (automatic optical level) method was established as a standard method of high precision (control). Pearson's correlation was performed with quota values determined by the assessed leveling methods. The absolute volume of soil embankment for geometric leveling with that calculated by the other methods was analyzed with the respective error calculations regarding the geometric leveling.

\section{RESULTS AND DISCUSSION}

Figure $5 \mathrm{~A}$ shows the DTM obtained by the most accurate method, i.e., the geometric leveling, in which the equipment called automatic optical level is used. According to Tuler \& Saraiva (2014), geometric (automatic) leveling stands out in topographic studies for its higher precision (in the order of millimeters) than other surveys. 
A

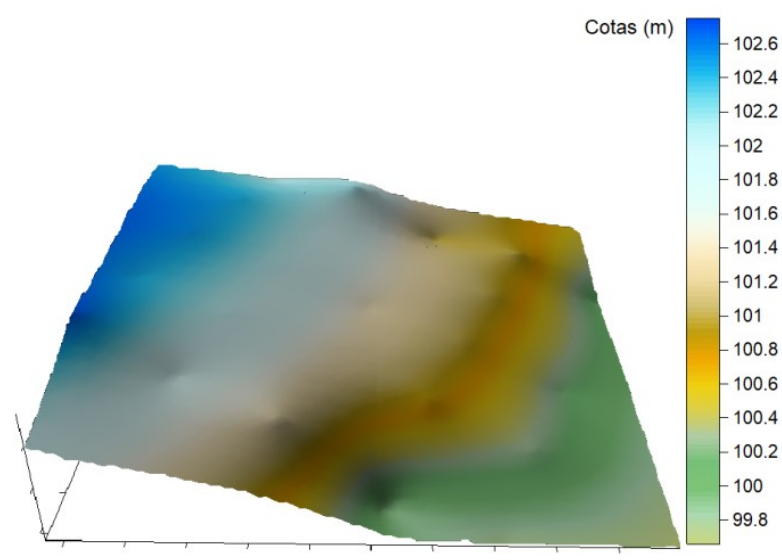

C

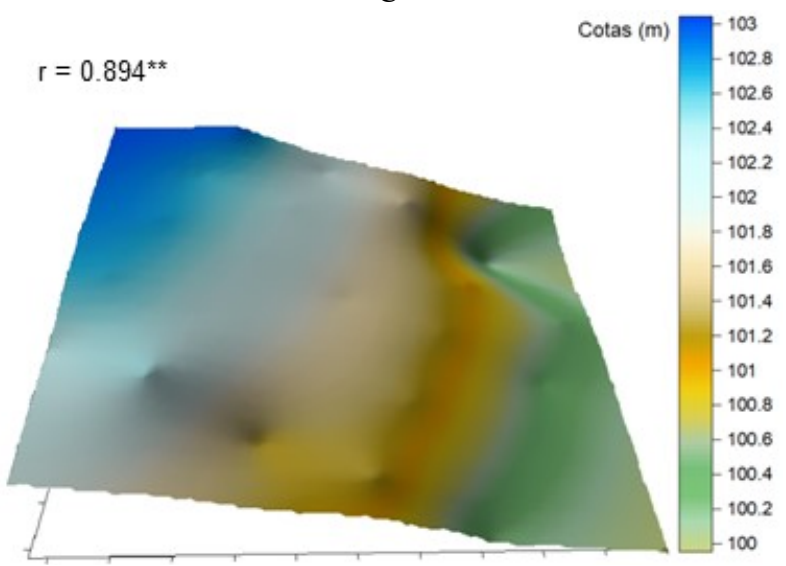

E

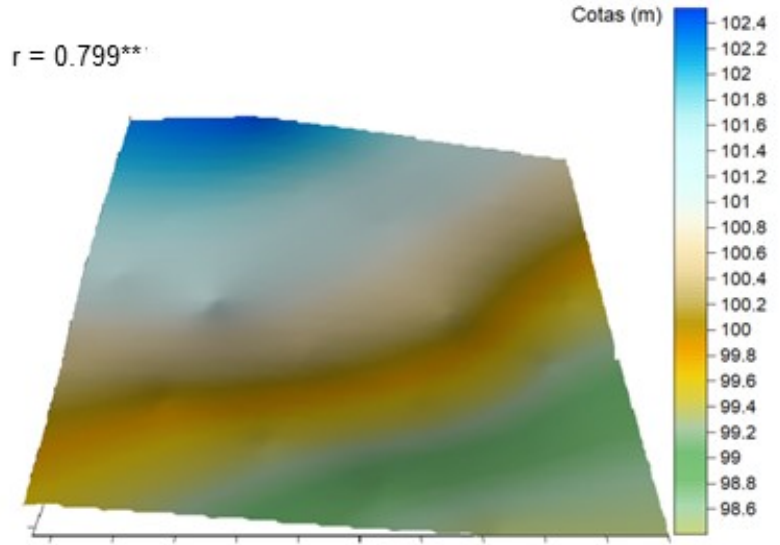

B

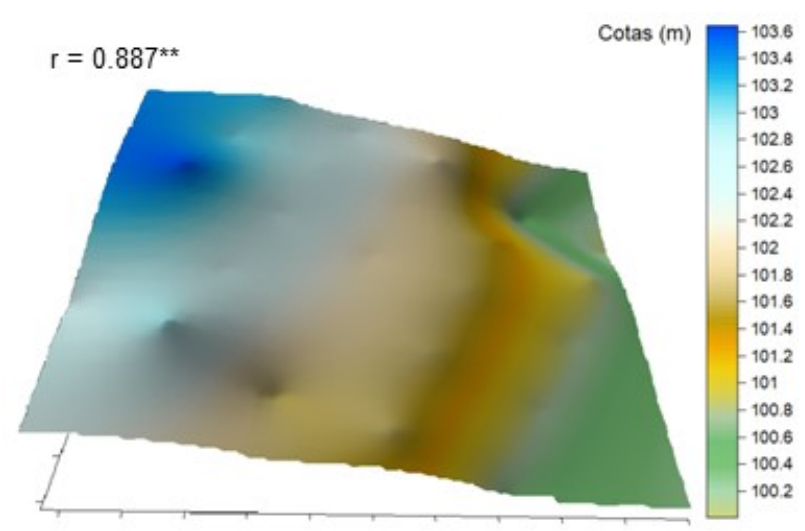

D

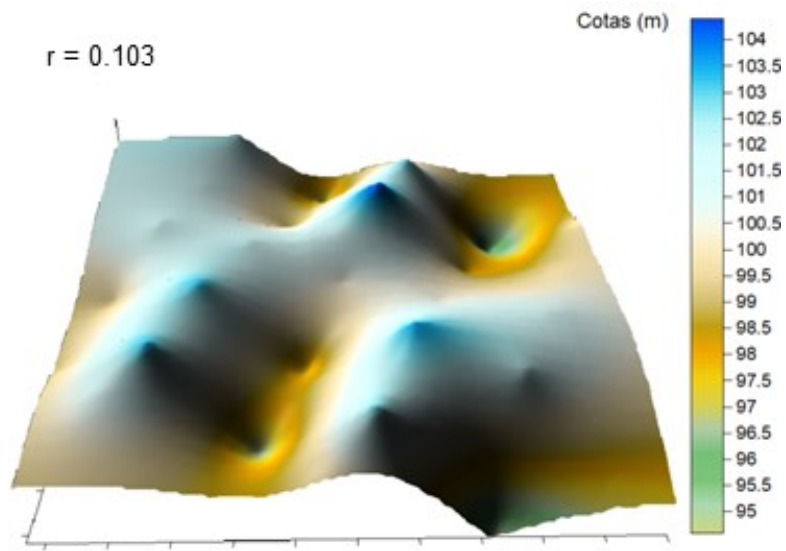

F

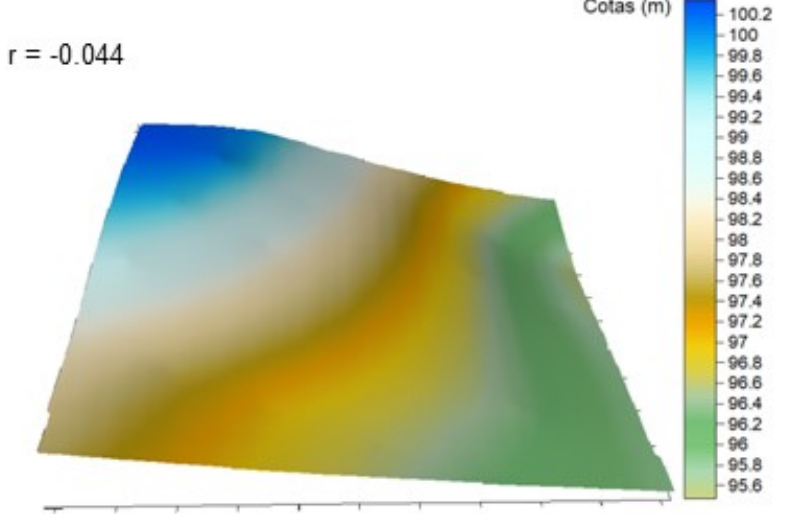

FIGURE 5. 3D terrain models assembled by geometric leveling (A), GNSS leveling by approximate positioning (B), total station by trigonometric leveling (C), GPS leveling by absolute positioning (D), ASTER image dimensioning (E), and image extraction by SRTM (F), with correlation coefficients of grid dimensions by the ethical method and other leveling methods at the level of $\mathrm{p}=0.01^{* *}$.

Surveys performed from GNSS leveling by relative positioning (Figure 5B) and total station (Figure 5C) were the most similar to the geometric leveling, with significant $(\mathrm{p}<0.01)$ and very high correlations $(0.9>\mathrm{r}>0.7)$ (Hopkins, 2000). Gomes et al. (2014) found that the trigonometric leveling, using medium-precision instruments, presents altimetric precision close to the survey by geometric leveling (with standard deviation ranging from \pm 10 to \pm 1 $\mathrm{mm} \mathrm{km}{ }^{-1}$ ), thus being a good alternative for some engineering services.

An uncharacterized terrain in relation to geometric leveling was observed in the GPS leveling by absolute positioning, with low $(0.3>\mathrm{r}>0.1)$ and non-significant
( $p>0.05$ ) correlation, which is due to the lower precision of this equipment (above $10 \mathrm{~m}$ ) (Monico, 2008). Franco (2009) obtained similar results and observed that navigation GNSS/GPS receivers by absolute position do not offer sufficient precision to answer technical and legal demands, which in the planimetric method should be higher or equal to $0.50 \mathrm{~m}$ for artificial limits and higher or equal at $3.00 \mathrm{~m}$ for natural limits (Brasil, 2013).

The main difference between navigation GNSS/GPS receivers and a geodetic GNSS is that in the former, point positioning (absolute) is used in real-time, providing its position instantly. These types of receivers are unsuitable for activities that require high accuracy and 
precision, as they cannot store the data generated from the pseudo-distance (raw data), transmitted by satellites of the GPS (Matsuoka et al., 2008). However, the collection of planialtimetric data by geodesic GNSS occurs through the use of a pair of receiving antennas, with fixed and mobile bases (rover), the latter together with the operator transmitting the collection information as relative positioning (Alves et al., 2015). The advantage of this type of tracking is its precision, as they use L1 and L1/L2 carrier waves, with millimeter precision, differently from GNSS/GPS navigation (Castilho \& Franzoso, 2014).

Images from the digital terrain elevation model (Figures 5E and 5F), on the other hand, showed a slight inclination in the direction of the slope compared to the standard method, with a significant correlation for the ASTER image and non-significant for the SRTM image. On the contrary, Biffi et al. (2013) demonstrated that SRTM data have a lower altimetric error than ASTER.

Soil cutting volumes were calculated (Figure 6), and a soil volume of $10,333.33 \mathrm{~m}^{3}$ was determined by the geometric leveling method (GL). The estimate by trigonometric leveling by the total station (TS) was the most similar to the geometric leveling, with a volume of $10,269.48 \mathrm{~m}^{3}$, i.e., a difference of $0.62 \%$ lower than the estimated soil.

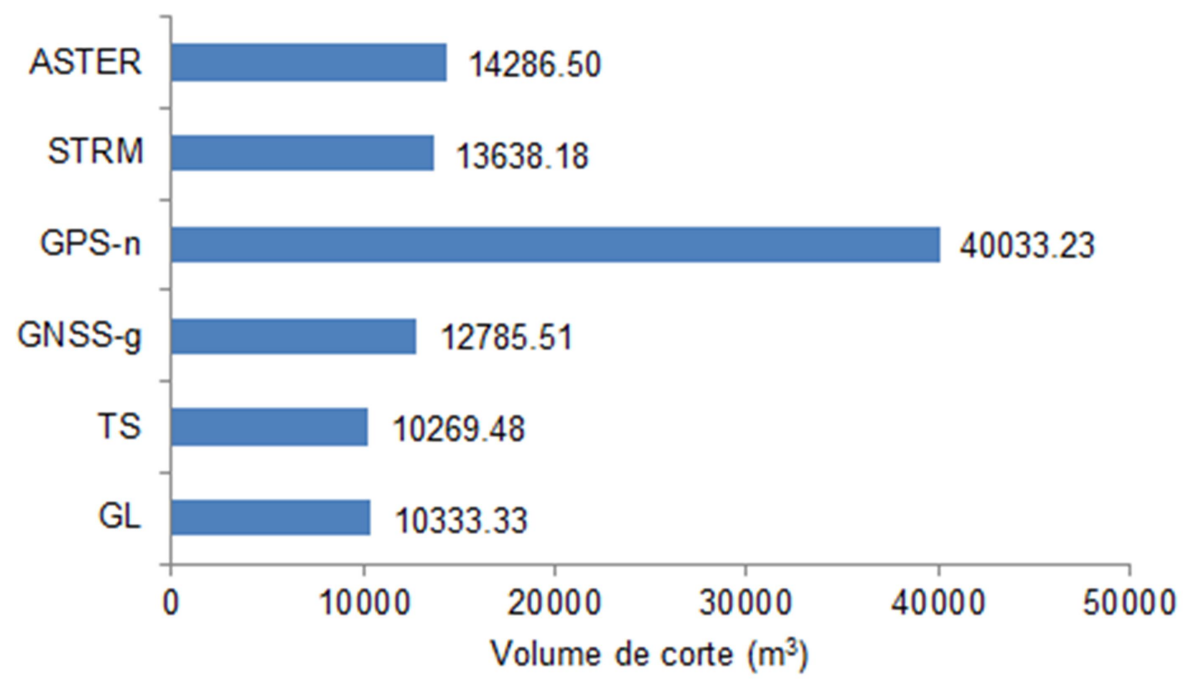

FIGURE 6. Cutting volumes determined by different altimetric survey methods.

The method with the highest error was GPS leveling by absolute positioning (GPS-n), which estimated a volume of $40,033.23 \mathrm{~m}^{3}$, equivalent to $287.42 \%$ more soil than geometric leveling. The GNSS leveling method by relative positioning (GNSS-g), although considered a precise method in determining the level difference (Santos et al., 2011), estimated a volume of $12,785.51 \mathrm{~m}^{3}$, resulting in $23.73 \%$ more volume.

SRTM and ASTER images had volumes of $13,638.18$ and $14,286.50 \mathrm{~m}^{3}$, respectively, with surpluses equivalent to 31.98 and $38.26 \%$ more soil, resulting in lower precision than GNSS leveling by relative positioning. Although relatively high errors were observed in determining soil volumes using images, their use in other types of altimetric surveys cannot be ruled out, as their application will depend on the Cartographic Accuracy Standard required for the work (Morais et al., 2017).

Souza \& Matricardi (2013) evaluated different DEMs (SRTM, ASTER GDEM, and TOPODATA) in determining the length and slope factor of the universal soil loss equation and did not find any significant difference, with very similar values for annual soil loss (1.70, 1.67, and 1.76, respectively), between models of the LS factor (influence of topography) and USLE (universal soil loss equation) with the different evaluated DEMs, attributing this result to the flat and slightly wavy configuration of the surface of the studied Environmental Protection Areas. Also, Datta \& Schack-Kirchner (2010) compared three sources of digital elevation models (DEM) (SRTM, ASTER, and one generated from contour lines) in a small basin in India and observed with field measurements that SRTM was the most suitable in ideal spatial resolution of DEM for hydrological modeling for the basin under study.

The results demonstrate that, in the case of measuring soil volumes for topographical purposes, geotechnologies should be used with caution because earthworks can represent up to $25 \%$ of the total cost of road works and may be even higher in other works, with higher difficulty of execution, corroborating the study of Hare et al. (2011).

\section{CONCLUSIONS}

Trigonometric leveling presented an error lower than $1 \%$ in the determination of soil volumes when compared to geometric leveling. The GNSS/GPS receiver by absolute positioning (using $\mathrm{C} / \mathrm{A}$ code) provided the highest error in determining soil volumes. The values of soil volumes obtained by GNSS leveling (relative positioning) and SRTM and ASTER images provided a high soil volume, not being recommended for earthworks.

\section{REFERENCES}

ABNT - Associação Brasileira de Normas Técnicas (1994) NBR 13133: Norma de execução de levantamento topográfico. ABNT, p01-35.

Alves DCL, Gandra TBR, Albuquerque MG (2015)

Metodologia de coleta e tratamento de dados topográficos para elaboração de modelos digitais de elevação em áreas urbanas. Scientia Plena 11(2):1-7. 
Biffi LJ, Jarenkow GL, Franchini RL (2013) Comparação de modelos digitais de elevação de SRTM e ASTER com modelo de elevação de grande escala do município de Lages - SC. In: Simpósio Brasileiro de Sensoriamento Remoto. Rio de Janeiro, Sociedade Brasileira de Sensoriamento Remoto. Anais...

Brasil (2013) Norma técnica para georreferenciamento de imóveis rurais. Brasília, DF, Ministério do Desenvolvimento Agrário, $4 \mathrm{p}$.

Camargo LCG (2017) Cálculo do volume de corte e aterro do solo por diferentes métodos de levantamento planialtimétrico. In: Congresso Nacional de Iniciação Científica. Santo Amaro, FMP, Anais...

Castilho SD, Franzoso LFF (2014) Análise de ferramentas e processos utilizados em levantamento georreferenciado. Retec - Revista de Tecnologias 7(1):101-114.

Coelho Junior JM, Rolim Neto FC, Andrade JSCO (2014) Topografia geral. Recife, EDUFRPE, v1, p59-72.

Datta PS, Schack-Kirchner H (2010) Erosion relevant topographical parameters derived from different DEMs: a comparative study from the Indian Lesser Himalayas. Remote Sensing 2(8):1941-1961.

Doma M, Sedeek A (2019) Accuracy assessment of DEMs using modern geoinformatic methods. Geoinformatica An International Journal (GIIJ) 6(2):13-22.

Hare W L, Koch VR, Lucet Y (2011) Models and algorithms to improve earthwork operations in road design using mixed integer linear programming. European Journal of Operational Research 215(2):470-480

Franco TCR (2009) Análise da precisão no posicionamento com um receptor GPS de navegação. Revista Agrogeoambiental 1(3):79-86.

Gomes RH, Santos AP, Poz WRD (2014) Comparação do nivelamento trigonométrico, pelo método leap-frog utilizando instrumentos de média precisão, com o nivelamento geométrico de precisão. In: Congresso Brasileiro de Geoprocessamento, Porto Alegre, Sociedade Brasileira de Cartografia, Geodésia, Fotogrametria e Sensoriamento Remoto.
Hopkins WG (2000) A new view of statistics. Internet Society for Sport Science. Available:

http://www.sportsci.org/resource/stats/. Accessed Feb 20, 2019.

Matsuoka MT, Soares DM, Souza SF, Veronez MR (2008) Análise da aplicação de receptor GPS de navegação no posicionamento relativo estático de linha-base curta. Gaea - Journal Of Geoscience 4(2):88-93.

Morais JD, Faria TS, Elmiro MAT, Nero MA, Silva AA, Nobrega RAA (2017) Altimetry assessment of ASTER GDEM v2 and SRTM v3 digital elevation models: a case study in urban area of Belo Horizonte, MG, Brazil. BCG Bulletin of Geodetic Sciences 23(4):654-668.

Monico JFG (2008) Posicionamento pelo GNSS: descrição, fundamentos e aplicações. São Paulo, UNESP, p313-329.

Pittella MS, Salbego AG (2014) Aplicação da topografia na engenharia civil. In: Salão Internacional de Ensino, Pesquisa e Extensão. Bagé, Universidade Federal do Pampa, Anais...

Rossi MS, Freitas ER, Vanzela LS (2015) Determinação de volume de solo por diferentes métodos de levantamento planialtimétrico. In: Encontro de Pós-graduação, Encontro de Iniciação Científica, Fernandópolis, Universidade Camilo Castelo Branco.

Santos MST, Amaro VE, Souto MVS (2011) Metodologia geodésica para levantamento de linha de costa e modelagem digital de elevação de praias arenosas em estudos de precisão de geomorfologia e dinâmica costeira. Revista Brasileira de Cartografia 63(5):663-681.

Souza GM, Matricardi EAT (2013) Análise comparativa dos modelos de elevação SRTM, ASTER GDEM e TOPODATA para estimar o fator topográfico (LS) da USLE. In: Simpósio Brasileiro de Sensoriamento Remoto, Porto Alegre, Sociedade Brasileira de Sensoriamento Remoto, Anais...

Testoni AJ, Backes FA, Antonello L (2009) A importância da topografia na recuperação de áreas degradadas. Revista Ágora: Revista de Divulgação Científica 16(2):52-62.

Tuler M, Saraiva S (2014) Fundamentos de topografia. Porto Alegre, Bookman, p133-184. 